\title{
CHEMICAL COMPOSITION OF Hypericum rochelii GRISEB. \& SCHENK HEADSPACE VOLATILES
}

Aleksandra Đorđević*, Gordana Stojanović

(ORIGINAL SCIENTIFIC PAPER)

UDC 615.322:543.544/.632

Department of Chemistry, Faculty of Science and Mathematics, University of Niš, Niš, Serbia

The present study reports the chemical composition of Hypericum rochelii headspace volatiles, obtained from fresh roots, stems, leaves and fruits by HS-GC-MS technique. The volatiles obtained from fresh roots and fruits are reported for the first time. Forty-seven constituents were identified in total, 28 components in the fruit volatiles, 19 components in the leaf volatiles, 33 components in the stem volatiles, and 31 components in the root volatiles, accounting for 99.8, 97.9, 99.4 and $93.8 \%$ of the total volatiles, respectively. The components that were found in significant amounts in the analysed samples were (E)-2-hexenal, nonane, $\alpha$-pinene, $\beta$-pinene and undecane.

\section{Introduction}

Hypericum L. (Guttiferae/Clusiaceae/Hypericaceae) is a genus represented by more than 480 species, widespread in warm-temperate areas throughout the world [1]. Both extracts and essential oils of Hypericum species have been shown to possess significant antiviral, wound healing, antioxidant and antimicrobial properties [2,3], so the number of studies on Hypericum species has increased rapidly over the years.

Eighteen Hypericum species inhabit the territory of Serbia [4] with Hypericum rochelii as one of them. Hypericum rochelii is a perennial herb, $15-50 \mathrm{~cm}$ tall, erect to ascending, sometimes rooting, with few stems, unbranched below inflorescence or (very rarely) branched throughout when ascending. Stems are terete, eglandular, not glaucous with triangular-lanceolate or upper triangularovate leaves, and inflorescences 3-25-flowered, without lower branches or rarely with one to numerous flowering branches [5].

Up to now, there has been only one study dealing with essential oil composition of $H$. rochelii isolated from fresh aerial parts. [6]. Since the data on the chemical composition of $H$. rochelii volatiles are scarce, the aim of this study was to perform a compositional analysis of the volatiles obtained from fresh roots, stems, leaves and fruits by headspace (HS) technique. Data concerning the volatiles obtained from fresh roots and fruits are reported for the first time.

\section{Experimental}

\section{Plant material}

Plant material was collected in the fruiting stage from the area of Rtanj Mountain (southeastern Serbia) in June 2018. Voucher specimens were deposited in the Herbarium of the Faculty of Science and Mathematics, University of Niš, under the acquisition number 13859. The fresh plant was divided into parts: root, stem, leaf and fruit.

\section{Headspace volatiles}

For the HS experiment, chopped plant material $(0.5 \mathrm{~g})$ was put into $20 \mathrm{~mL}$ HS vial than soaked with $2 \mathrm{~mL}$ of distilled water. The sample was heated at $80{ }^{\circ} \mathrm{C}$ for 20 minutes with the following mixing program: shaking for 5 seconds, pausing for 2 seconds.

\section{GC and GC-MS analyses}

GC-MS analysis (three repetitions) was performed using an Agilent Technologies 7890B GC equipped with a fused silica capillary column (HP-5MS, $250 \mu \mathrm{m} \times 25 \mathrm{~m}$, film thickness $0.25 \mu \mathrm{m}$, Agilent Technologies, USA) and coupled with a 7890A flame ionization detector (FID) and 5977A MS detector of the same brand, recording at $70 \mathrm{eV}$. Full scan spectra were acquired over the range $35-500$ amu (scan time 5 scans/second). The GC-MS was operated under the following conditions: injector temperature $250{ }^{\circ} \mathrm{C}$; GC-MS interface temperature $300{ }^{\circ} \mathrm{C}$; oven temperature programmed from $50^{\circ}$ to $200{ }^{\circ} \mathrm{C}$ at $4{ }^{\circ} \mathrm{C} /$ minute, carrier gas $\mathrm{He}, 1.0 \mathrm{~mL} / \mathrm{min}$, constant flow mode, vacuum outlet $(37 \mathrm{~cm} / \mathrm{second}$ linear velocity); injected volume $500 \mu \mathrm{L}$

\footnotetext{
*Author adress: Aleksandra Đorđević, Department of Chemistry, Faculty of Science and Mathematics,

University of Niš, Višegradska, 18000 Niš, Serbia

E-mail: sanjadj81@yahoo.com

The manuscript received: October, 15, 2019.

Paper accepted: November, 04, 2019.

Paper accepted: October, 14, 2019.
} 
of HS volatiles, split ratio 40:1. The constituents were identified by comparison of their linear retention indices relative to the retention times of C8-C40 n-alkanes on the HP-5MS column [7] with literature values [8] and their mass spectra with those of authentic standards, as well as those from Wiley 6, NIST11, Agilent Mass Hunter Workstation B.06.00 software [9] and a homemade MS library with the spectra corresponding to pure substances and components of known essential oils, and wherever possible, by co-injection with an authentic sample. GC-FID was carried out under the same conditions as described for the GC-MS. The percentage composition of the oil was computed from the GC peak areas without the use of any correction factors.

\section{Results and discussion}

The compounds identified in $H$. rochelii HS volatiles obtained from fresh roots, stems, leaves and fruits are listed in Table 1. Forty-seven constituents were identified in total, 28 components in the fruit volatiles, 19 components in the leaf volatiles, 33 components in the stem volatiles, and 31 components in the root volatiles, accounting for $99.8,97.9,99.4$ and $93.8 \%$ of the total volatiles, respectively (Table 1). Twelve components out of all were found to be present as mutual volatiles obtained from all plant parts (namely, nonane, a-thujene, a-pinene, sabinene, $\beta$-pinene, myrcene, $p$-cymene, limonene, ( $Z$ )- $\beta$-ocimene, $(E)-\beta$-ocimene, $\gamma$-terpinene and undecane). Twenty-six compounds were found in traces (with percentage less than $0.05 \%$ ) at least in one of the HS samples.

Nonane (45.8\%), $\beta$-pinene (27.1\%), $\alpha$-pinene (19.1\%) and undecane $(4.7 \%)$ were the most abundant components of the fruit volatiles while the leaf volatiles were represented by $(E)-2$-hexenal $(29.2 \%)$, $\beta$-pinene $(22.5 \%)$, $\alpha$-pinene $(15.6 \%)$, nonane $(6.1 \%)$ and hexanal $(5.9 \%)$. The main stem volatiles were $\alpha$-pinene (35.1\%), $\beta$-pinene (33.5\%), nonane $(18.3 \%)$ and undecane $(4.3 \%)$ (Table 1). Headspace volatiles of the root were characterized by undecane $(76.1 \%)$, $\beta$-pinene $(7.9 \%)$ and decane $(4.0 \%)$. The fruit and leaf volatiles were almost evenly distributed between mono- (47.9 and 54.3\%, respectively) and nonterpenoids (51.5 and $42.0 \%$, respectively). Non-terpenoid fraction of the leaf volatiles was characterized by a large amount of aldehydes (42.0\%), namely $(E)$-2-hexenal and hexanal. This compound class (aldehydes) was present in small quantities or was not present at all in HS volatiles of any other plant parts (Table 1). The root volatiles were characterized by a large amount of non-terpenoids $(82.5 \%)$, mostly due to the main compound - undecane which made up about three quarters of the total percentage composition. In all samples under study, monoterpenoids were dominated by hydrocarbons (fruit, leaf, stem, root $-47.9,52.1,72.4$ and $10.6 \%$ respectively), versus oxygenated components. Also, non-terpenoid compounds consisted mainly of n-alkanes except in the case of the leaf volatiles (Table 1).

Apart from our study, there is only one paper dealing with $H$. rochelii volatiles [6]. The authors reported n-nonane $(24.7 \%)$, $\beta$-pinene $(22.4 \%)$, germacrene D $(7.5 \%)$, n-undecane $(6.8 \%)$ and $\alpha$-pinene $(5.8 \%)$ as the main constituents of the essential oil composition of $\mathrm{H}$. rochelii isolated from fresh aerial parts. The above-mentioned monoand non-terpenoids were in agreement with HS samples under study obtained from the corresponding plant parts (Table 1).

\section{Conclusions}

A detailed investigation on $H$. rochelii headspace volatiles obtained from fresh roots, stems, leaves and fruits resulted in the identification of forty-seven constituents. The present findings improved the knowledge about the chemical composition of $H$. rochelii species which has been insufficiently investigated up to now (some data herein were reported for the first time). Headspace technique proved to be a very fast and simple method for sample preparation (especially when plant material is scarce), and gives acceptable analyses results.

\section{Acknowledgments}

This work was financially supported by the Ministry of Education, Science and Technological Development of the Republic of Serbia (project no.172047). 
Table 1. Percentage composition of $H$. rochelii HS volatiles

\begin{tabular}{|c|c|c|c|c|c|c|c|c|}
\hline Entry & $\mathbf{R I}^{\mathbf{a})}$ & $\mathrm{Al}^{\text {a) }}$ & Component & Fruit & Leaf & Stem & Root & Identification $^{\text {b) }}$ \\
\hline 1. & 800 & 800 & Octane & 0.9 & - & 3.1 & 0.3 & RI, MS, Col \\
\hline 2. & 803 & 801 & Hexanal & - & 5.9 & - & - & RI, MS, Col \\
\hline 3. & 850 & 846 & (E)-2-Hexenal & - & 29.2 & 0.3 & - & RI, MS \\
\hline 4. & 900 & 900 & Nonane & 45.8 & 6.1 & 18.3 & 0.2 & RI, MS, Col \\
\hline 5. & 924 & 924 & $\alpha$-Thujene & 0.3 & 0.4 & 0.5 & 0.2 & RI, MS \\
\hline 6. & 932 & 932 & $\alpha$-Pinene & 19.1 & 15.6 & 35.1 & 1.9 & RI, MS, Col \\
\hline 7. & 948 & 946 & Camphene & 0.1 & - & 0.2 & 0.1 & RI, MS \\
\hline 8. & 970 & 969 & Sabinene & $\operatorname{tr}$ & 0.5 & 0.2 & $\operatorname{tr}$ & RI, MS \\
\hline 9. & 975 & 974 & $\beta$-Pinene & 27.1 & 22.5 & 33.5 & 7.9 & RI, MS, Col \\
\hline 10. & 990 & 988 & Myrcene & 0.5 & 1.1 & 0.8 & 0.1 & RI, MS, Col \\
\hline 11. & 998 & 998 & Octanal & $\operatorname{tr}$ & - & - & - & RI, MS \\
\hline 12. & 1000 & 1000 & Decane & 0.1 & - & 0.3 & 4.0 & RI, MS, Col \\
\hline 13. & 1005 & 1002 & a-Phellandrene & $\operatorname{tr}$ & - & - & - & RI, MS \\
\hline 14. & 1015 & 1014 & $\alpha$-Terpinene & 0.1 & - & 0.1 & - & RI, MS \\
\hline 15. & 1020 & 1020 & $p$-Cymene & $\operatorname{tr}$ & 2.2 & 0.2 & 0.1 & RI, MS, Col \\
\hline 16. & 1025 & 1024 & Limonene & 0.6 & 1.2 & 0.7 & 0.1 & RI, MS, Col \\
\hline 17. & 1026 & 1026 & 1,8-Cineole & $\operatorname{tr}$ & 0.9 & - & 0.1 & RI, MS, Col \\
\hline 18. & 1035 & 1032 & (Z)- $\beta$-Ocimene & $\operatorname{tr}$ & 3.2 & 0.4 & $\operatorname{tr}$ & RI, MS \\
\hline 19. & 1045 & 1044 & $(E)-\beta$-Ocimene & $\operatorname{tr}$ & 2.9 & 0.4 & 0.1 & RI, MS \\
\hline 20. & 1055 & 1054 & $\mathrm{Y}$-Terpinene & 0.1 & 2.5 & 0.2 & 0.1 & RI, MS \\
\hline 21. & 1090 & 1086 & Terpinolene & $\operatorname{tr}$ & - & 0.1 & - & RI, MS \\
\hline 22. & 1100 & 1100 & Undecane & 4.7 & 0.8 & 4.3 & 76.1 & RI, MS, Col \\
\hline 23. & 1100 & 1100 & Nonanal & $\operatorname{tr}$ & $\operatorname{tr}$ & $\operatorname{tr}$ & - & RI, MS \\
\hline 24. & 1143 & 1141 & Camphor & - & 0.6 & - & - & RI, MS, Col \\
\hline 25. & 1160 & 1155 & Isoborneol & - & 0.7 & - & - & RI, MS \\
\hline 26. & 1190 & 1186 & $\alpha$-Terpineol & $\operatorname{tr}$ & - & - & - & $\mathrm{RI}, \mathrm{MS}$ \\
\hline 27. & 1200 & 1200 & Dodecane & - & - & - & 0.4 & RI, MS, Col \\
\hline 28. & 1201 & 1201 & Decanal & $\operatorname{tr}$ & - & $\operatorname{tr}$ & - & RI, MS \\
\hline 29. & 1300 & 1300 & Tridecane & $\operatorname{tr}$ & - & 0.1 & 1.5 & RI, MS, Col \\
\hline 30. & 1348 & 1345 & $\alpha$-Cubebene & - & - & $\operatorname{tr}$ & $\operatorname{tr}$ & RI, MS \\
\hline 31. & 1350 & 1350 & $\alpha$-Longipinene & 0.3 & - & 0.1 & 0.1 & RI, MS \\
\hline 32. & 1376 & 1373 & $\alpha$-Ylangene & - & - & - & 0.2 & RI, MS \\
\hline 33. & 1380 & 1374 & a-Copaene & $\operatorname{tr}$ & - & $\operatorname{tr}$ & 0.3 & RI, MS \\
\hline 34. & 1390 & 1387 & $\beta$-Cubebene & - & - & - & $\operatorname{tr}$ & RI, MS \\
\hline 35. & 1400 & 1400 & $\beta$-Longipinene & $\operatorname{tr}$ & - & - & - & RI, MS \\
\hline 36. & 1410 & 1409 & a-Gurjunene & - & - & - & $\operatorname{tr}$ & $\mathrm{RI}, \mathrm{MS}$ \\
\hline 37. & 1420 & 1417 & (E)-Caryophyllene & 0.1 & - & 0.1 & $\operatorname{tr}$ & RI, MS, Col \\
\hline 38. & 1431 & 1430 & $\beta$-Copaene & - & - & $\operatorname{tr}$ & - & $\mathrm{RI}, \mathrm{MS}$ \\
\hline 39. & 1480 & 1475 & trans-Cadina-1(6),4-diene & - & - & $\operatorname{tr}$ & $\operatorname{tr}$ & RI, MS \\
\hline 40. & 1482 & 1478 & Y-Muurolene & - & - & 0.1 & $\operatorname{tr}$ & RI, MS \\
\hline 41. & 1485 & 1484 & Germacrene D & - & 1.6 & 0.1 & - & $\mathrm{RI}, \mathrm{MS}$ \\
\hline 42. & 1500 & 1500 & Pentadecane & - & - & - & $\operatorname{tr}$ & RI, MS, Col \\
\hline 43. & 1502 & 1495 & cis-Cadina-1,4-diene & - & - & $\operatorname{tr}$ & $\operatorname{tr}$ & RI, MS \\
\hline 44. & 1515 & 1513 & $\mathrm{Y}$-Cadinene & - & - & 0.1 & - & RI, MS \\
\hline 45. & 1526 & 1521 & trans-Calamenene & - & - & - & $\operatorname{tr}$ & RI, MS \\
\hline 46. & 1530 & 1522 & $\delta$-Cadinene & - & - & 0.1 & $\operatorname{tr}$ & RI, MS \\
\hline 47. & 1538 & 1533 & trans-Cadina-1,4-diene & - & - & $\operatorname{tr}$ & - & RI, MS \\
\hline \multirow[t]{13}{*}{ Total } & & & & 99.8 & 97.9 & 99.4 & 93.8 & \\
\hline & & & Monoterpenoids & 47.9 & 54.3 & 72.4 & 10.7 & \\
\hline & & & Monoterpene & 47.9 & 52.1 & 72.4 & 10.6 & \\
\hline & & & hydrocarbons & & & & & \\
\hline & & & Oxygenated monoterpenes & $\operatorname{tr}$ & 2.2 & - & 0.1 & \\
\hline & & & Sesquiterpenoids & 0.4 & 1.6 & 0.6 & 0.6 & \\
\hline & & & Sesquiterpene & 0.4 & 1.6 & 0.6 & 0.6 & \\
\hline & & & hydrocarbons & & & & & \\
\hline & & & Oxygenated & - & - & - & - & \\
\hline & & & sesquiterpenes & & & & & \\
\hline & & & Non-terpenoids & 51.5 & 42.0 & 26.4 & 82.5 & \\
\hline & & & n-Alkanes & 51.5 & 6.9 & 26.1 & 82.5 & \\
\hline & & & Aldehydes & $\operatorname{tr}$ & 35.1 & 0.3 & - & \\
\hline \multicolumn{9}{|c|}{$\begin{array}{l}\text { a) Rl: Experimentally determined retention indices on the mentioned column by co-injection of a homologous series of } n \text { - } \\
\text { alkanes } \mathrm{C}_{8}-\mathrm{C}_{20} \text { and } \mathrm{C}_{21}-\mathrm{C}_{40} ; \mathrm{Al} \text { : Literature retention indices [8]. }\end{array}$} \\
\hline \multicolumn{9}{|c|}{ b) Identification method: RI, retention indices matching with literature data; MS, mass spectra matching with literature data; } \\
\hline $\mathrm{Col}, \mathrm{co}$ & ection wi & an auth & ntic sample. & & & & & \\
\hline
\end{tabular}




\section{References}

[1] S. L. Crockett, N. K. B. Robson, Taxonomy and chemotaxonomy of the genus Hypericum, Medicinal and Aromatic Plant Science and Biotechnology, 5 (1) (2011) 1-13.

[2] K. H. C. Baser, G. Buchbauer (Eds.), Handbook of Essential Oils: Science, Technology and Applications, CRC Press, Taylor and Francis Group, USA, 2010.

[3] Z. Saddiqe, I. Naeem, A. Maimoona, A review of the antibacterial activity of Hypericum perforatum L., Journal of Ethnopharmacology, 131 (3) (2010) 511-521.

[4] L. Stjepanović-Veselčić, Rod Hypericum. In: Flora SR Srbije 3, M. Josifović (Ed.), SANU, Beograd, 1972, p.104125.

[5] N. K. B. Robson, Studies in the genus Hypericum L. (Hypericaceae) 5(1). Sections 10. Olympia to 15/16. Crossophyllum, Phytotaxa, 4 (2010) 5-126.
[6] A. Đorđević, J. Lazarević, A. Šmelcerović, G. Stojanović, The case of Hypericum rochelii Griseb. \& Schenk and Hypericum umbellatum A. Kern. essential oils: chemical composition and antimicrobial activity, Journal of Pharmaceutical and Biomedical Analysis, 77 (2013) 145-148.

[7] H. Van den Dool, P. D. Kratz, A generalization of the retention index system including linear temperature programmed gasliquid partition chromatography, Journal of Chromatography A, 11 (1963) 463-471.

[8] R. P. Adams, Identification of essential oil components by gas chromatography/mass spectrometry, Allured publishing corporation, Illinois, USA, 2007.

[9] S. E. Stein, National institute of standards and technology (NIST) mass spectral database and software, Version 3.02., 1990.

Izvod

\section{HEMIJSKI SASTAV "HEADSPACE" ISPARLJIVIH KOMPONENTI BILJNE VRSTE Hypericum rochelii GRISEB. \& SCHENK}

Aleksandra Đorđević, Gordana Stojanović
(ORIGINALNI NAUČNI RAD) UDC 615.322:543.544/.632

Departman za hemiju, Prirodno-matematički fakultet, Univerzitet u Nišu, Niš, Srbija

U ovom radu objavljen je hemijski sastav "headspace" isparljivih komponenti izolovanih iz svežeg korena, stabla, lista i ploda biljne vrste Hypericum rochelii, tehnikom "headspace"-gasna hromatografija-masena spektrometrija (HS-GCMS). "Headspace" isparljive komponente izolovane iz korena i ploda objavljene su po prvi put. Identifikovano je ukupno 47 komponenti, od toga, 28 u plodu, $19 \mathrm{u}$ listu, 33 u stablu i 31 u korenu, što iznosi 99,8\%, 97,9\%, 99,4\% i 93,8\% od ukupnih isparljivih komponenti. Komponente, identifikovane u značajnom procentu u svim analiziranim uzorcima su (E)-2-heksenal, nonan, $\alpha$-pinen, $\beta$-pinen i undekan.
Ključne reči: Hypericum rochelii, hemijski sastav, GC-MS, "headspace" isparljiva jedinjenja 